\title{
Regulation effects of water and nitrogen on potato dry matter and nitrogen accumulation and partitioning
}

\author{
Li Wen-ting ${ }^{1,2} \bullet$ Wang Shi-wen ${ }^{1,3 *} \bullet$ Deng Xi-ping ${ }^{1,3} \bullet$ Yin Li-na ${ }^{1,3} \bullet$ Li Hong-bing $^{1,3}$
}

\footnotetext{
${ }^{1}$ State Key Laboratory of Soil Erosion and Dryland Farming on the Loess Plateau, Institute of Soil and Water Conservation, Northwest A\&F University, Yangling 712100, P. R. China.

${ }^{2}$ Institute of Agricultural Resources and Economics, Shanxi Academy of Agricultural Sciences, Taiyuan 030006, P.R. China. ${ }^{3}$ Institute of Soil and Water Conservation, Chinese Academy of Sciences and Ministry of Water Resources, Yangling 712100, P.R. China.
}

${ }^{*}$ Corresponding author. E-mail: shiwenwang@nwsuaf.edu.cn. Tel: +86-29-87012872.

Accepted 14 ${ }^{\text {th }}$ December, 2018.

\begin{abstract}
In order to maximize potato tuber yield and nitrogen uptake, it is important to optimize the management practices related to dry matter $(\mathrm{DM})$ and nitrogen $(\mathrm{N})$ accumulation and partitioning. To evaluate the effects of water and $\mathrm{N}$ level on DM and $\mathrm{N}$ accumulation and partitioning during the tuber bulking stage in the potato, a pot experiment was conducted with three water levels $\left(90 \%, 70 \%\right.$, and $50 \%$ of field capacity) and three $\mathrm{N}$ levels $\left(0,85.5\right.$ and $\left.171 \mathrm{~kg} \mathrm{~N} \mathrm{ha}^{-1}\right)$. The results showed that potato tuber yield and tuber $\mathrm{N}$ uptake were significantly affected by the water levels, $\mathrm{N}$ levels, and the interaction between water and $\mathrm{N}$. Under the watered and moderate $\mathrm{N}$ conditions $(90 \%$ of field capacity and 85.5 $\mathrm{kg} \mathrm{N} \mathrm{ha}^{-1}$ ), the tuber yield and $\mathrm{N}$ uptake were the highest. Watered conditions, moderate $\mathrm{N}$ conditions, and the watered combined with moderate $\mathrm{N}$ condition increased the tuber yield and tuber $\mathrm{N}$ uptake by increasing the accumulation of total DM and $\mathrm{N}$ in the plant, while not by increasing the partitioning of DM and $\mathrm{N}$ to tubers. Therefore, these results suggest that optimizing water and $\mathrm{N}$ management to improve DM and $\mathrm{N}$ accumulation is the key to ensuring high tuber yield and $\mathrm{N}$ uptake in the potato.
\end{abstract}

Keywords: Potato, water, nitrogen, dry matter, accumulation, partitioning.

\section{INTRODUCTION}

Potato (Solanum tuberosum L.) is an important food crop that is grown in many regions throughout the world. The tuber is an important source of starch in human diets and contains large amounts of nutritious compounds, such as vitamin $C$, several $B$ vitamins, vitamin $A$ and potassium (Camire et al., 2009). It is also an industrial material that can be used to produce ethanol (Srichuwong et al., 2009). Thus, there is growing demand for potatoes for food, feed, and industrial products (Birch et al., 2012). Understanding the patterns of dry matter (DM) and nitrogen $(\mathrm{N})$ accumulation and partitioning in potato plants is useful in the improvement of potato yield and $\mathrm{N}$ uptake (Alva et al., 2002).

Water is essential for plant growth and it dramatically affects potato growth and yield (Bélanger et al., 2001). The potato is sensitive to water stress, even slight water shortage can cause a reduction in tuber yield, especially during the tuber bulking stage (an Loon, 1981). Previous studies showed that water level significantly affects potato plant $\mathrm{DM}$ and $\mathrm{N}$ accumulation, while its effect on the partitioning of DM to tubers is conflicting: some studies reported that there was no significant difference in the partitioning of DM to tubers under different water levels whereas others put forth that water deficiency 
Table 1. Water and nitrogen levels in different treatments.

\begin{tabular}{|c|c|}
\hline Water & Nitrogen \\
\hline \multirow{3}{*}{ Watered ( $90 \%$ of field capacity) } & Low nitrogen ( $0 \mathrm{mg} \mathrm{N}$ added to per $\mathrm{kg}$ soil) \\
\hline & Moderate nitrogen (200 mg N added to per $\mathrm{kg}$ soil) \\
\hline & High nitrogen (400 mg N added to per kg soil) \\
\hline \multirow{3}{*}{ Moderate stress ( $70 \%$ of field capacity) } & Low nitrogen ( $0 \mathrm{mg} \mathrm{N}$ added to per $\mathrm{kg}$ soil) \\
\hline & Moderate nitrogen (200 mg N added to per $\mathrm{kg}$ soil) \\
\hline & High nitrogen (400 mg N added to per kg soil) \\
\hline \multirow{3}{*}{ Droughted ( $50 \%$ of field capacity) } & Low nitrogen ( $0 \mathrm{mg} \mathrm{N}$ added to per $\mathrm{kg}$ soil) \\
\hline & Moderate nitrogen (200 $\mathrm{mg} \mathrm{N}$ added to per $\mathrm{kg}$ soil) \\
\hline & High nitrogen (400 mg N added to per kg soil) \\
\hline
\end{tabular}

increased DM partitioning to tubers (Wolfe et al., 1983; Bélanger et al., 2001; Liu et al., 2015). Thus, how water level affects DM and $\mathrm{N}$ accumulation and partitioning and influences potato yield and $\mathrm{N}$ uptake remains unclear.

$\mathrm{N}$ is also an important crop management consideration that affects tuber yield in potato production (Badr et al., 2012). Potato is sensitive to $\mathrm{N}$ stress. Deficient and excess $\mathrm{N}$ conditions result in a low yield (Geary et al., 2015). Many studies reported that although there was an increase in the amount of total DM and $\mathrm{N}$ that the plant accumulated with more $\mathrm{N}$ available, the partitioning of DM to tubers was not affected by $\mathrm{N}$ levels, and the proportion of $\mathrm{N}$ recovered in tubers decreased with increased $\mathrm{N}$ level (Kleinkopf et al., 1981; Millard et al., 1989; Vos, 1997; Sharifi et al., 2005). How the N level affects DM and $\mathrm{N}$ accumulation and partitioning to influence potato yield and $\mathrm{N}$ uptake remains poorly understood.

In agricultural production, water and $\mathrm{N}$ often interact (Sadras et al., 2016; Kunrath et al., 2018). As dynamic processes in plant growth and development, DM and $\mathrm{N}$ accumulation and partitioning are often influenced by it (Chen and Setter, 2012; Fernandes et al., 2015). The effect of water and $\mathrm{N}$ on the $\mathrm{DM}$ and $\mathrm{N}$ accumulation and partition, and subsequently on the yield and $\mathrm{N}$ uptake during the tuber bulking stage in the potato is unclear. Therefore, the objective of this study was to evaluate the effect of water and $\mathrm{N}$ levels on the DM and $\mathrm{N}$ accumulation and partitioning during the tuber bulking stage in the potato, and to examine the effects of these different patterns on tuber yield and $\mathrm{N}$ uptake.

\section{MATERIALS AND METHODS}

\section{Plant material and experimental conditions}

The pot experiment was conducted in Yangling, Shaanxi province, China $\left(34^{\circ} 12^{\prime} \mathrm{N}, 108^{\circ} 7^{\prime} \mathrm{E}\right.$, and altitude $\left.530 \mathrm{~m}\right)$. On April 11, 2014, virus-free plantlets of the potato cultivar Atlantic, with uniform height (approximately 20 $\mathrm{cm}$ ), were transplanted into plastic pots (diameter $30 \mathrm{~cm}$, height $30 \mathrm{~cm}$ ). There was one plantlet per pot, and each pot was filled with $9.5 \mathrm{~kg}$ air-dried loessal soil and placed in a field under a transparent rainfall shelter to exclude natural precipitation. The loessal soil contained $2.4 \mathrm{~g} \mathrm{~kg}^{-1}$ organic matter, $0.32 \mathrm{~g} \mathrm{~kg}^{-1}$ total $\mathrm{N}, 0.68 \mathrm{~g} \mathrm{~kg}^{-1}$ total $\mathrm{P}$, $19.6 \mathrm{~g} \mathrm{~kg}^{-1}$ total $\mathrm{K}, 16.91 \mathrm{mg} \mathrm{kg}^{-1} \mathrm{NO}_{3}-\mathrm{N}$, and $38.72 \mathrm{mg}$ $\mathrm{kg}^{-1} \mathrm{NH}_{4}{ }^{+} \mathrm{N}$, with a $\mathrm{pH}$ of 8.27 . Soil gravimetric water content was maintained at $90 \%$ of field capacity by adding sufficient water at 18:00 h every day in all pots before the beginning of tuber bulking ( 26 days after transplanting [DAT]).

The experiment comprised nine treatments, representing all combinations of three water levels and three $\mathrm{N}$ levels (Table 1). For three water levels, soil gravimetric water content was maintained at $90 \%$ of field capacity for the watered group, $70 \%$ for the moderate stress group and $50 \%$ for the droughted group. Each water level was imposed from 26 DAT and was achieved by withholding watering based on weighing pots every day. $\mathrm{N}$ levels (designated as low, moderate, and high) were chosen on the basis of our preliminary experiment to allow unlimited growth at the moderate level and to limit growth at the low and high levels. Three $\mathrm{N}$ levels, 0 , 200 , and $400 \mathrm{mg} \mathrm{N} \mathrm{kg}^{-1}$ soil, were equivalent to $0,85.5$ and $171 \mathrm{~kg} \mathrm{~N} \mathrm{ha}^{-1}$, since potato are planted at a density of 45,000 plants ha $^{-1}$ generally. $\mathrm{N}$ fertilizer was applied according to each treatment using urea $(46 \% \mathrm{~N})$. Phosphate and potassium fertilizers were applied at a rate of $200 \mathrm{mg} \mathrm{P}_{2} \mathrm{O}_{5}$ and $100 \mathrm{mg} \mathrm{K} \mathrm{O}_{2} \mathrm{O}$ per kilogram soil for every treatment (equivalent to $85.5 \mathrm{~kg} \mathrm{P}_{2} \mathrm{O}_{5} \mathrm{ha}^{-1}$ and 42.8 $\left.\mathrm{kg} \mathrm{K}_{2} \mathrm{O} \mathrm{ha}^{-1}\right)$, in the form of $\mathrm{Ca}\left(\mathrm{H}_{2} \mathrm{PO}_{4}\right)_{2}$ and $\mathrm{K}_{2} \mathrm{SO}_{4}$, respectively. $\mathrm{N}$, phosphate, and potassium fertilizers were evenly incorporated with soil before transplanting. Every treatment had 45 pots, and different treatments were displayed in a randomized complete block design. At 69 DAT, the experiment was terminated.

\section{Plant sampling}

At 26, 36, 47, 58, and 69 DAT, eight plants were sampled 
Table 2. Tuber yield and tuber $\mathrm{N}$ uptake under different water and $\mathrm{N}$ levels.

\begin{tabular}{|c|c|c|c|}
\hline Treatment & & Tuber yield (g plant $\left.{ }^{-1}\right)$ & Tuber $\mathrm{N}$ uptake (mg plant $\left.{ }^{-1}\right)$ \\
\hline \multirow{3}{*}{ Watered } & Low N & $174 \pm 4^{c}$ & $219 \pm 5^{e}$ \\
\hline & Moderate $\mathrm{N}$ & $273 \pm 14^{\mathrm{a}}$ & $546 \pm 27^{a}$ \\
\hline & High N & $216 \pm 8^{b}$ & $361 \pm 14^{\mathrm{cd}}$ \\
\hline \multirow{3}{*}{ Moderate stress } & Low N & $164 \pm 3^{\mathrm{cd}}$ & $179 \pm 3^{e}$ \\
\hline & Moderate $\mathrm{N}$ & $257 \pm 10^{a}$ & $413 \pm 16^{\mathrm{bc}}$ \\
\hline & High N & $200 \pm 11^{b}$ & $416 \pm 23^{b}$ \\
\hline \multirow{3}{*}{ Droughted } & Low N & $147 \pm 2^{\mathrm{de}}$ & $175 \pm 2^{\mathrm{e}}$ \\
\hline & Moderate $\mathrm{N}$ & $207 \pm 8^{b}$ & $403 \pm 15^{\mathrm{bc}}$ \\
\hline & High N & $135 \pm 12^{\mathrm{e}}$ & $313 \pm 28^{d}$ \\
\hline \multicolumn{4}{|l|}{ ANOVA } \\
\hline Water level & & ** & ** \\
\hline $\mathrm{N}$ level & & ** & ** \\
\hline Water $\times \mathrm{N}$ & & ** & ** \\
\hline
\end{tabular}

Values are presented as the mean \pm SE of eight replicates. Values followed by the same letter in the columns were not significantly different according to Duncan's test at $P=0.05$; ${ }^{* \star}$ Significant at the 0.01 probability level.

per treatment. Whole plants were harvested, divided into plant shoots (leaves and stems), roots, and tubers, and washed to remove soil residues. Tubers larger than $1 \mathrm{~cm}$ in diameter were weighed and then sliced thinly. Plant shoots, roots, and tuber slices were then dried at $70^{\circ} \mathrm{C}$ until they reached a constant weight for DM determination. The dried samples were then ground, passed a 40-mesh screen, and analyzed for $\mathrm{N}$ concentration. The concentration of $\mathrm{N}$ in different plant parts was measured by the standard macro-Kjeldahl method according to Nelson and Sommers (1973).

Tuber yield was calculated as the tuber fresh weight per plant at 69 DAT. Tuber $\mathrm{N}$ uptakes were calculated by multiplying the tuber dry weight by the tuber $\mathrm{N}$ concentration at 69 DAT. The total DM accumulation of the whole plant was calculated as the sum of the dry weight of plant shoots, roots, and tubers. The amount of $\mathrm{N}$ accumulated in each plant portion was calculated by multiplying the $\mathrm{N}$ concentration by the dry weight of each plant part. Then, the values obtained in each plant portion were added up to determine the total $\mathrm{N}$ accumulation in the plant. DM partitioning to tubers was determined from the tuber dry weight as a percentage of whole plant dry weight, that is, the harvest index. $\mathrm{N}$ partitioning to tubers was determined from the amount of $\mathrm{N}$ accumulated in tubers as a percentage of the amount of total $\mathrm{N}$ accumulated in the plant, that is, the $\mathrm{N}$ harvest index. The specific equations were as follows:

Total plant dry weight $(\mathrm{g} /$ plant $)=$ Shoots dry weight + Roots dry weight + Tubers dry weight

Total $\mathrm{N}$ content $(\mathrm{mg} / \mathrm{plant})=$ Shoots dry weight $\times \mathrm{N}$ concentration in shoots + Roots dry weight $\times \mathrm{N}$ concentration in roots + Tubers dry weight $\times \mathrm{N}$ concentration in tubers

Harvest index $(\%)=$ Tubers dry weight $/$ Total plant dry weight

$\mathrm{N}$ harvest index $(\%)=$ Tubers $\mathrm{N}$ content $/$ Total $\mathrm{N}$ content

\section{Statistical analysis}

Statistical analyses were performed using the SPSS statistical software (Version 19.0 for Windows, SPSS, Chicago, USA). Analysis of variance (ANOVA) was used to assess the effect of water, $\mathrm{N}$, and their interaction on the related parameters. Treatment means were compared using the Duncan's test at a $5 \%$ level of significance.

\section{RESULTS AND DISCUSSION}

Among the environment factors that can be modified by farmers, water and $\mathrm{N}$ levels are the two main ones affecting plant growth (Gonzalez-Dugo et al., 2010). Several studies have demonstrated that crop yield is directly related to water and $\mathrm{N}$ levels in soil (Mueller et al., 2012). In our study, potato tuber yield and $\mathrm{N}$ uptake were both significantly affected by water levels, $\mathrm{N}$ rates, and the interaction between water and $\mathrm{N}$ (Table 2). Among three water levels, there was an increase in tuber yield and $\mathrm{N}$ uptake with the application of moderate $\mathrm{N}$ compared with low $\mathrm{N}$. While high $\mathrm{N}$ level did not further increase tuber yield and $\mathrm{N}$ uptake, it resulted in a lower yield and $\mathrm{N}$ uptake. This suggests that the $\mathrm{N}$ fertilizer 


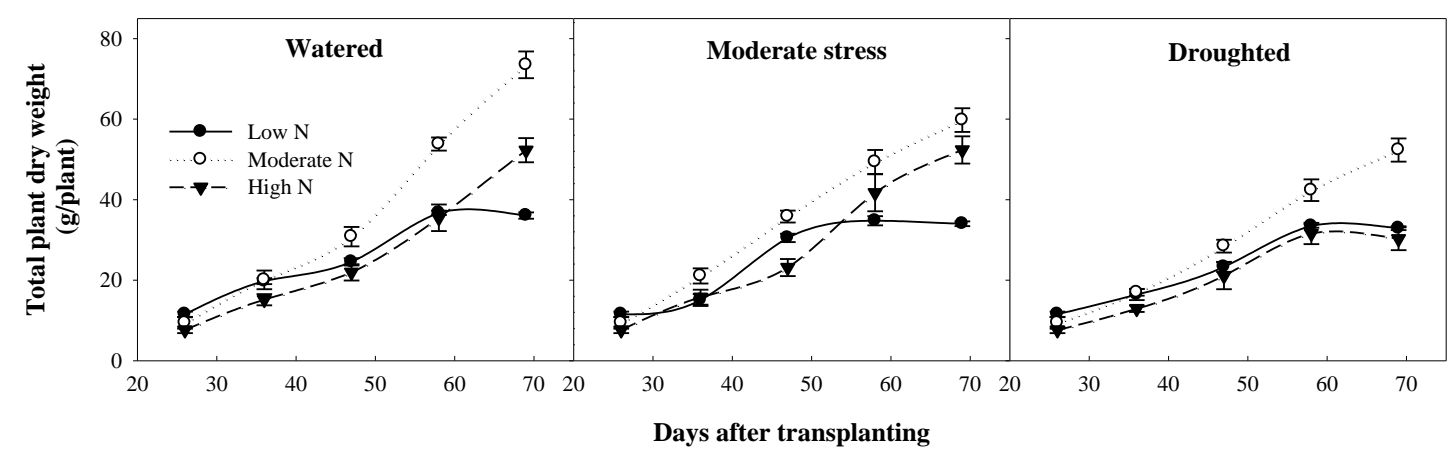

Figure 1. Total DM accumulation in potato plants at different days after transplanting under different water and $\mathrm{N}$ levels. Data are presented as the mean \pm standard error $(\mathrm{SE}, \mathrm{n}=5)$.

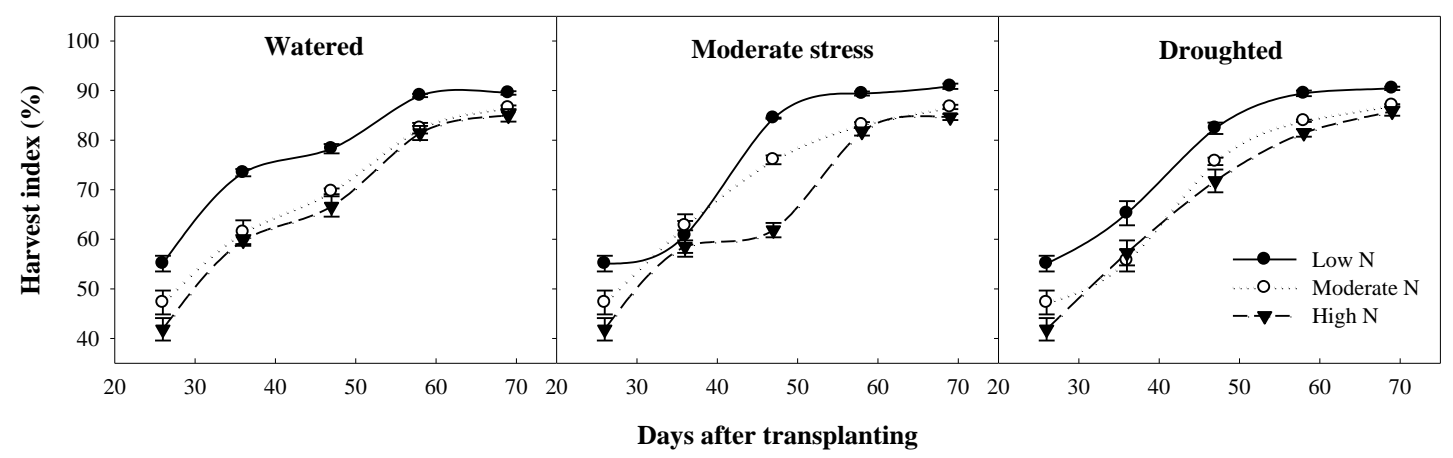

Figure 2. Harvest index for tubers in potato plants at different days after transplanting under different water and $\mathrm{N}$ levels. Data are presented as the mean $\pm \operatorname{SE}(n=5)$.

dose is not the more the better for the potato yield and $\mathrm{N}$ uptake. Moderate $\mathrm{N}$ rate $\left(85.5 \mathrm{~kg} \mathrm{~N} \mathrm{ha}^{-1}\right)$ was beneficial for potato production, while low $\left(0 \mathrm{~kg} \mathrm{~N} \mathrm{ha}^{-1}\right)$ or high (171 $\mathrm{kg} \mathrm{N} \mathrm{ha}^{-1}$ ) $\mathrm{N}$ rates would restrict tuber yield and $\mathrm{N}$ uptake. Among three $\mathrm{N}$ rates, watered plants (90\% field capacity) had higher tuber yield and $\mathrm{N}$ uptake than plants under water stress (70 and $50 \%$ of field capacity). It suggests that the growth of potato requires a great deal of water, water deficiency would restrict potato growth and $\mathrm{N}$ uptake, and then result in a low yield. In water combined with $\mathrm{N}$ conditions, tuber yield and $\mathrm{N}$ uptake was highest under the watered combined with moderate $\mathrm{N}$ condition. This means that watered, moderate $\mathrm{N}$ and watered combined with moderate $\mathrm{N}$ conditions were beneficial for tuber yield and $\mathrm{N}$ uptake improvement. This is in agreement with the findings of lerna et al. (2011), who reported that the highest potato yield was achieved under irrigation at $100 \%$ of the maximum evapotranspiration (ETM) and a medium fertilization level (100 $\mathrm{kg} \mathrm{ha}^{-1}$ of $\left.\mathrm{N}\right)$.

Potato yield depends on the amount of total DM the plant accumulates and the amount of DM that is partitioned to the tubers, that is, the harvest index (Jenkins and Mahmood, 2003). In our study, in terms of tuber bulking, the total DM accumulation and harvest index in the potato plant increased with time under all water and $\mathrm{N}$ levels although the amounts differed with different treatments (Figures 1 and 2). Among the three water levels, although there was no apparent difference in the harvest index, watered plants accumulated more total DM than plants under water stress, which resulted in a higher yield (Table 2; Figures 1 and 2). This suggests that watered conditions are beneficial for potato DM accumulation, it increased tuber yield by increasing the accumulation of total DM but not by increasing the partitioning of DM to tubers. This is consistent with the findings of Wolfe et al. (1983). Among the three N levels, plants with moderate $\mathrm{N}$ accumulated the highest amount of total DM and tuber yield, but the harvest index was not highest under this condition (Table 2; Figures 1 and 2). Under low $\mathrm{N}$ levels, although the harvest index was the highest, the amount of total DM the plant accumulated was lower, which resulted in a lower yield. Under high $\mathrm{N}$ levels, because both the total DM accumulation and harvest index were lower, plants had a lower tuber yield. Thus, the highest tuber yield with moderate $\mathrm{N}$ was attributed to the highest amount of total DM the plant accumulated. Millard and Marshall (1986) also reported similar results that potato yield increases were due to the 


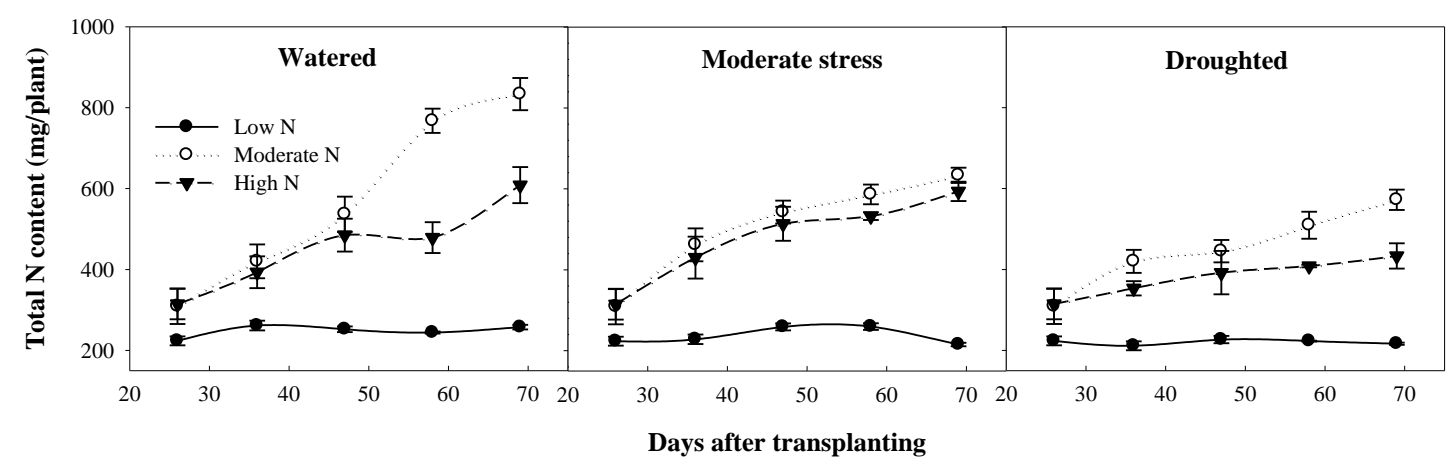

Figure 3. Total $\mathrm{N}$ accumulation in potato plants at different days after transplanting under different water and $\mathrm{N}$ levels. Data are presented as the mean \pm SE $(n=5)$.

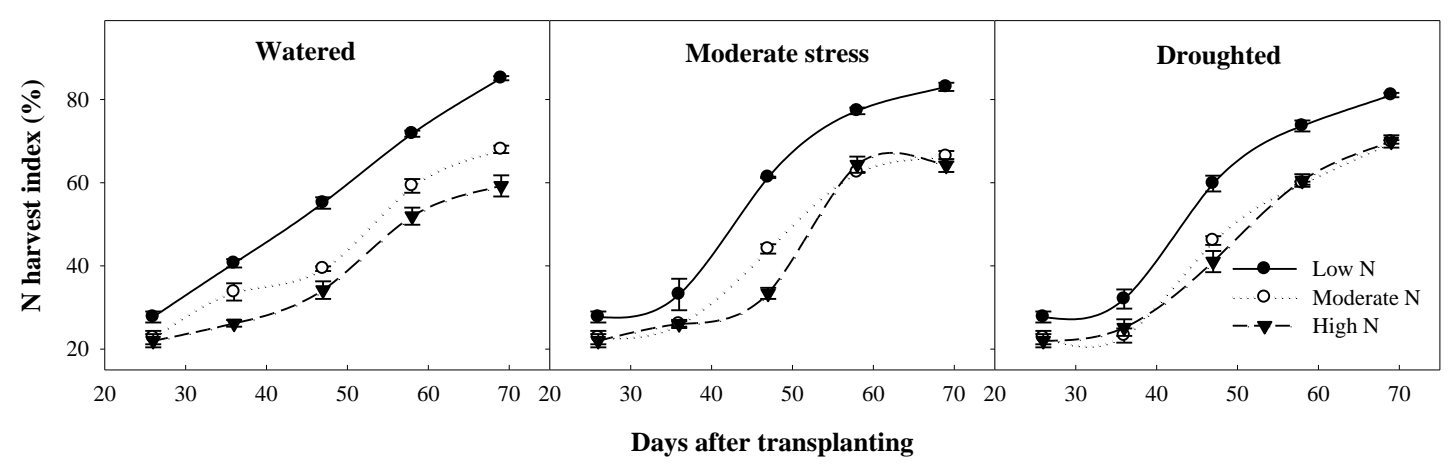

Figure 4. Harvest index for $\mathrm{N}$ in potato plants at different days after transplanting under different water and $\mathrm{N}$ levels. Data are presented as the mean \pm SE $(n=5)$.

increased accumulation of total DM. In water combined with $\mathrm{N}$ conditions, the total DM the plant accumulated, and tuber yield were both highest under the watered combined with moderate $\mathrm{N}$ condition, but the harvest index was not highest under this condition. This suggests that the watered combined with moderate $\mathrm{N}$ condition is beneficial for potato DM accumulation, but it did not promote the partitioning of DM to tubers. Thus, the increased tuber yield under this condition was due to the increased accumulation of total DM in the plant but not to the increased partitioning of DM to tubers.

Nitrogen is an essential element for maintaining the physiological activities of plants. Understanding the patterns of plant $\mathrm{N}$ accumulation and partitioning is important for increasing crop $\mathrm{N}$ uptake (Hirel et al., 2007). For tuber bulking, the amount of total $\mathrm{N}$ the plant accumulated increased with time under moderate and high $\mathrm{N}$ conditions for all the three water levels, but the amount of total $\mathrm{N}$ in low $\mathrm{N}$ plants did not change obviously (Figure 3 ). This may be because, under low $\mathrm{N}$ conditions, the plants could not accumulate more $\mathrm{N}$ because of soil $\mathrm{N}$ deficiency. The $\mathrm{N}$ harvest index increased with time for all water and $\mathrm{N}$ levels (Figure 4). This indicated that more $\mathrm{N}$ in the potato plant was translocated into the tubers during tuber bulking phase. Among the three water levels, since $\mathrm{N}$ is taken up with water, the amount of total $\mathrm{N}$ the plant accumulated under water stress was lower than that under watered conditions, though there was no significant difference in the $\mathrm{N}$ harvest index (Figures 3 and 4). This suggests that the higher tuber $\mathrm{N}$ uptake under watered conditions resulted from the higher accumulation of total $\mathrm{N}$ in the plant. Among the three $\mathrm{N}$ levels, plants with moderate $\mathrm{N}$ accumulated the most $\mathrm{N}$, but the $\mathrm{N}$ harvest index was not highest under this condition (Figures 3 and 4). At low $\mathrm{N}$ levels, as in Millard et al.'s report (1989), the $\mathrm{N}$ harvest index was higher than it was at moderate $\mathrm{N}$ and high $\mathrm{N}$ levels, but the accumulation of plant total $\mathrm{N}$ was the lowest. Under high $\mathrm{N}$ levels, the total $\mathrm{N}$ the plant accumulated and the $\mathrm{N}$ harvest index were lower. This suggests that the higher tuber $\mathrm{N}$ uptake with moderate $\mathrm{N}$ was due to the higher amount of total $\mathrm{N}$ the plant accumulated. In water combined with $\mathrm{N}$ conditions, plants with watered and moderate $\mathrm{N}$ accumulated the most total $\mathrm{N}$, but these plants did not have the highest $\mathrm{N}$ harvest index. This means that the highest tuber $\mathrm{N}$ uptake under the watered combined with moderate $\mathrm{N}$ condition was due to the highest accumulation of total $\mathrm{N}$ in the plant. 
Therefore, like tuber yield, the increased tuber $\mathrm{N}$ uptake is attributed to the increased accumulation of total $\mathrm{N}$ in the plant.

On the whole, the patterns of plant DM and $\mathrm{N}$ accumulation and partitioning were obviously affected by the water and $\mathrm{N}$ levels. Understanding the changes of these patterns under different water and $\mathrm{N}$ levels is important for improving potato yield and $\mathrm{N}$ uptake. Watered and moderate $\mathrm{N}$ conditions $(90 \%$ of field capacity and $85.5 \mathrm{~kg} \mathrm{~N} \mathrm{ha}^{-1}$ ) were beneficial for potato yield, $\mathrm{N}$ uptake, $\mathrm{DM}$ and $\mathrm{N}$ accumulation during the tuber bulking stage, but were not beneficial for the partitioning of $\mathrm{DM}$ and $\mathrm{N}$ to tubers. Thus, watered conditions, moderate $\mathrm{N}$ conditions, and the watered combined with moderate $\mathrm{N}$ condition increased the tuber yield and tuber $\mathrm{N}$ uptake by increasing the accumulation of total DM and $\mathrm{N}$ in the plant, but not by increasing the partitioning of DM and $\mathrm{N}$ to tubers. Therefore, optimizing water and $\mathrm{N}$ management to improve the accumulation of total DM and $\mathrm{N}$ during the tuber bulking stage is important for increasing tuber yield and $\mathrm{N}$ uptake in potato production.

\section{ACKNOWLEDGEMENT}

This study was supported by Youth Innovation Promotion Association of the Chinese Academy of Sciences (2013307), National Key Technology Support Program of China (2015BAD22B01), National Basic Research Program of China (2015CB150402) and the 111 Project of Chinese Education Ministry (B12007).

\section{REFERENCES}

Alva AK, Hodges T, Boydston RA, Collins HP (2002). Dry matter and nitrogen accumulations and partitioning in two potato cultivars. J. Plant Nutr. 25:1621-1630.

Bélanger G, Walsh JR, Richards JE, Milburn PH, Ziadi N (2001). Tuber growth and biomass partitioning of two potato cultivars grown under different $\mathrm{N}$ fertilization rates with and without irrigation. Am. J. Potato Res. 78:109-117.

Badr MA, El-Tohamy WA, Zaghloul AM (2012). Yield and water use efficiency of potato grown under different irrigation and nitrogen levels in an arid region. Agric. Water Manage. 110:9-15.

Birch PRJ, Bryan G, Fenton B, Gilroy EM, Hein I, Jones JT, Prashar A, Taylor MA, Torrance L, Toth IK (2012). Crops that feed the world 8: Potato: are the trends of increased global production sustainable? Food Secur. 4:477-508.

Camire ME, Kubow S, Donnelly DJ (2009). Potatoes and human health. Crit. Rev. Food Sci. Nutr. 49:823-840.

Chen CT, Setter TL (2012). Response of potato dry matter assimilation and partitioning to elevated $\mathrm{CO}_{2}$ at various stages of tuber initiation and growth. Environ. Exp. Bot. 80:27-34.

Fernandes AM, Soratto RP, Pilon C (2015). Soil phosphorus increases dry matter and nutrient accumulation and allocation in potato cultivars. Am. J. Potato Res. 92:117-127.
Geary B, Clark J, Hopkins BG, Jolley VD (2015). Deficient, adequate and excess nitrogen levels established in hydroponics for biotic and abiotic stress-interaction studies in potato. J. Plant Nutr. 38:41-50.

Gonzalez-Dugo V, Durand JL, Gastal F (2010). Water deficit and nitrogen nutrition of crops. A review. Agron. Sustainable Dev. 30:529544

Hirel B, Le Gouis J, Ney B, Gallais A (2007). The challenge of improving nitrogen use efficiency in crop plants: towards a more central role for genetic variability and quantitative genetics within integrated approaches. J. Exp. Bot. 58:2369-2387.

lerna A, Pandino G, Lombardo S, Mauromicale G (2011). Tuber yield, water and fertilizer productivity in early potato as affected by a combination of irrigation and fertilization. Agric. Water Manage. 101:35-41.

Jenkins PD, Mahmood S (2003). Dry matter production and partitioning in potato plants subjected to combined deficiencies of nitrogen, phosphorus and potassium. Ann. Appl. Biol. 143:215-229.

Kleinkopf GE, Westermann DT, Dwelle RB (1981). Dry matter production and nitrogen utilization by six potato cultivars. Agron. J. 73:799-802.

Kunrath TR, Lemaire G, Sadras Vo, Gastal F (2018). Water use efficiency in perennial forage species: interactions between nitrogen nutrition and water deficit. Field Crops Res. 222: 1-11.

Liu CX, Rubaek GH, Liu FL, Andersen MN (2015). Effect of partial root zone drying and deficit irrigation on nitrogen and phosphorus uptake in potato. Agric. Water Manage. 159:66-76.

Millard P, Marshall B (1986). Growth, nitrogen uptake and partitioning within the potato (Solatium tuberosum L.) crop, in relation to nitrogen application. J. Agric. Sci. 107:421-429.

Millard P, Robinson D, Mackie-Dawson LA (1989). Nitrogen partitioning within the potato (Solarium tuberosum L.) plant in relation to nitrogen supply. Ann. Bot. 63:289-296.

Mueller ND, Gerber JS, Johnston M, Ray DK, Ramankutty N, Foley JA (2012). Closing yield gaps through nutrient and water management. Nature. 490:254-257.

Nelson DW, Sommers LE (1973). Determination of total nitrogen in plant material. Agron. J. 65:109-112.

Sadras VO, Hayman PT, Rodriguez D, Monjardino M, Bielich M, Unkovich M, Mudge B, Wang E (2016). Interactions between water and nitrogen in Australian cropping systems: physiological, agronomic, economic, breeding and modelling perspectives. Crop Pasture Sci. 67:1019-1053.

Sharifi M, Zebarth BJ, Hajabbasi MA, Kalbasi M (2005). Dry matter and nitrogen accumulation and root morphological characteristics of two clonal selections of 'Russet Norkotah' potato as affected by nitrogen fertilization. J. Plant Nutr. 28:2243-2253.

Srichuwong S, Fujiwara M, Wang XH, Seyama T, Shiroma R, Arakane M, Mukojima N, Tokuyasu K (2009). Simultaneous saccharification and fermentation (SSF) of very high gravity (VHG) potato mash for the production of ethanol. Biomass Bioenergy. 33:890-898.

Van Loon CD (1981). The effect of water stress on potato growth, development, and yield. Am. Potato J. 58:51-69.

Vos J (1997). The nitrogen response of potato (Solanum tuberosum L.) in the field: nitrogen uptake and yield, harvest index and nitrogen concentration. Potato Res. 40:237-248.

Wolfe DW, Fereres E, Voss RE (1983). Growth and yield response of two potato cultivars to various levels of applied water. Irrig. Sci. 3:211-222.

http://www.sciencewebpublishing.net/jacr 